\title{
Short communication: The association of adiponectin and leptin concentrations with prepartum dietary energy supply, parity, body condition, and postpartum hyperketonemia in transition dairy cows
}

\author{
S. Mann, ${ }^{* 1}$ C. Urh, † H. Sauerwein,† J. J. Wakshlag,‡ F. A. Leal Yepes,§ T. R. Overton,§ and D. V. Nydam* \\ *Department of Population Medicine and Diagnostic Sciences, College of Veterinary Medicine, Cornell University, Ithaca, NY 14853 \\ †Institute for Animal Science, Physiology and Hygiene Unit, University of Bonn, 53115 Bonn, Germany \\ $\ddagger$ Department of Clinical Sciences, College of Veterinary Medicine, and \\ §Department of Animal Science, Cornell University, Ithaca, NY 14853
}

\section{ABSTRACT}

Adipokines - hormones produced by adipose tissue have important regulatory functions, and their concentrations can change around the time of calving when energy balance rapidly decreases. Hence, energy balance may be an important factor in determining the circulating concentrations of adipokines, particularly adiponectin and leptin. The objective of our study was to investigate the association between the level of energy fed to prepartum Holstein cows and circulating concentrations of adiponectin and leptin before and after calving. Holstein dairy cows entering second or greater lactation were fed either a controlled-energy diet formulated to supply approximately 100\% of energy requirements (n $=28$ ) or a high-energy diet formulated to supply approximately $150 \%$ of energy requirements throughout the entire dry period $(\mathrm{n}=28)$. Serum samples were analyzed for adiponectin and leptin concentrations at 56, 28,10 , and $1 \mathrm{~d}$ prepartum as well as on $\mathrm{d} 1,10,21$, and 42 postpartum using ELISA. Parity was dichotomized into cows entering second versus higher parity. Average peripartum body condition score (BCS) was computed from weekly measurements and dichotomized into animals with an average BCS of $\leq 3.25$ and $>3.25$. In addition, cows were classified according to the occurrence of hyperketonemia ( $\beta$-hydroxybutyrate concentrations $\geq 1.2 \mathrm{mmol} / \mathrm{L}$ at any time between 3 and $21 \mathrm{~d}$ in milk). Data were analyzed using repeated-measures ANOVA. Serum leptin but not adiponectin concentrations were associated with prepartum feeding level such that leptin concentrations increased transiently during the dry period in cows overfed energy, but concentrations were not different postpartum. Cows entering second parity had higher adiponectin and lower leptin concentrations compared with cows in higher parities. Cows

Received August 27, 2017.

Accepted September 9, 2017.

${ }^{1}$ Corresponding author: sm682@cornell.edu that developed hyperketonemia postpartum had consistently lower adiponectin concentrations during the study period. Cows with average BCS $>3.25$ had higher leptin concentrations during the dry period only, but adiponectin concentrations were not associated with BCS. In conclusion, prepartum energy level had only transient effects on leptin concentrations and did not lead to changes in adiponectin concentrations.

Key words: adiponectin, leptin, energy, hyperketonemia, transition

\section{Short Communication}

Adipose tissue is an endocrine organ secreting adipokines into circulation that exert different metabolic, reproductive, and immunological effects in dairy cows in an endocrine, autocrine, or paracrine manner (Sauerwein et al., 2014). Adiponectin and leptin are among the most abundant adipokines, and their concentrations change around the time of calving (Chilliard et al., 2005; Giesy et al., 2012). Changes in energy balance due to energy partitioning have been identified as potential key factors in these observed changes of circulating adiponectin (Singh et al., 2014a). Leptin concentration is known to be affected by energy balance in transition dairy cows and is positively correlated with insulin and glucose concentrations (Block et al., 2001, 2003). Recently, De Koster et al. (2017) reported a negative association between adiponectin concentrations and BCS during the dry period. Prepartum energy supply is associated with changes in energy balance and circulating insulin and glucose concentrations (Mann et al., 2016b) as well as degree of adipose tissue breakdown and postpartum hyperketonemia (elevated concentration of BHB concentrations between 3 and $21 \mathrm{~d}$ postpartum; Dann et al., 2006; Janovick et al., 2011; Mann et al., 2015). Previously we showed that gene expression of adiponectin was increased at d 10 prepartum in subcutaneous adipose tissue of cows overfed energy and with high concentrations of BHB postpartum compared 
with cows fed a controlled-energy diet and exhibiting low concentrations of BHB (Mann et al., 2016a). The objective of this study was to determine a possible association between the energy level in the dry period and the circulating concentrations of adiponectin and leptin in the transition period of Holstein dairy cows. In addition, we aimed to determine whether parity, BCS, and hyperketonemia, a condition typically associated with excessive negative energy balance postpartum (Baird et al., 1974; Herdt, 2000), were associated with differences in these 2 adipokines.

A detailed description of enrollment, treatment diets, and sampling procedures for the animals included in this study was published previously (Mann et al., 2015). Briefly, cows were randomly assigned to receive either a TMR formulated to supply approximately $100 \%$ of predicted energy requirements during the dry period $(\sim 57$ $\mathrm{d} ; \mathbf{C E} ; \mathrm{n}=28$ ) or a TMR that was formulated to supply approximately $150 \%$ of predicted energy requirements $(\mathbf{H E} ; \mathrm{n}=28)$. All animals were fed the same postpartum ration, and all diets were fed to allow a minimum of $5 \%$ of refusals. Cows were housed in tiestalls with feed bins. Serum samples were collected before morning feeding, aliquotted as previously described (Mann et al., 2015), and stored at $-80^{\circ} \mathrm{C}$ until analysis. To address the study objectives, serum samples were selected for the following time points: enrollment $(\sim 56 \mathrm{~d}$ before calving); 28, 10, and $1 \mathrm{~d}$ prepartum; and 1, 10, 21, and 42 d postpartum.

Leptin concentrations were measured using a competitive ELISA (Sauerwein et al., 2004). Adiponectin concentrations were measured with a bovine-specific indirect competitive ELISA as described previously (Mielenz et al., 2013) with modifications according to Kesser et al. (2015). The analytic sensitivity for leptin and adiponectin was 0.6 and $0.03 \mathrm{ng} / \mathrm{mL}$, respectively. The inter- and mean intra-assay coefficient of variation were 9.9 and $3.6 \%$ for leptin and 9.1 and $5.5 \%$ for adiponectin, respectively.

Body condition score was determined weekly by 1 of 2 trained investigators on a scale of 1 to 5 in 0.25 unit increments (Edmonson et al., 1989). Average BCS during the study period was calculated from weekly scores. Information on average weekly DMI and ultrasonographically assessed backfat thickness (BFT) at 6 time points of all cows was available (Mann et al., 2015, 2016a). Cows were classified as hyperketonemia positive (HYK) or negative (non-HYK) based on the presence or absence of at least 1 episode of whole-blood BHB $\geq 1.2 \mathrm{mmol} / \mathrm{L}$ between 3 and $21 \mathrm{DIM}$ when cows were sampled 3 times per week before the morning feeding.

For descriptive statistical analysis, the difference of average BCS between the 2 treatment groups was calculated using a 2-way ANOVA controlling for the effect of parity. Data collected over time were analyzed using repeated-measures ANOVA with the MIXED procedure in SAS (version 9.4; SAS Institute, Cary, NC). For both adiponectin and leptin the fixed effects included time, treatment group, average BCS, and parity in all models. In addition, the interaction of treatment group and time for the treatment group model, as well as the interaction between parity and time for the parity model, were included. Hyperketonemia status and the interaction of HYK with time were included only in the model describing its association with adipokines. To determine the association between body condition and adipokines, a separate model for each adipokine was built where the average BCS in the study period was dichotomized into 2 groups: $\leq 3.25$ and $>3.25$. The model included the fixed effect of BCS group, the interaction of BCS group and time, and the fixed effect of treatment group, time, and parity. The time variable was specified in all models as the repeated effect, and cow nested in treatment group was included as the subject effect. Covariance structures tested allowed for uneven spacing of samples over time and included unstructured, spatial power law, Gaussian, and spherical. The covariance structure resulting in the lowest Akaike information criterion was chosen for final analysis. Outlier diagnostics were performed after each model fit using the influence statement in the MIXED procedure of SAS for each animal. Animals were removed from the analysis following a predefined cutoff of Cook's D $\geq 0.5$. Residuals were evaluated for homoscedasticity and normality to satisfy model assumptions. Results are presented as mean or geometric mean and 95\% confidence interval unless otherwise specified.

Spearman rank correlation was computed for adiponectin and leptin with BFT, BCS, and average weekly DMI (CORR procedure, SAS version 9.4) at 4 time points throughout the study: 28 and $10 \mathrm{~d}$ before calving as well as 4 and $21 \mathrm{~d}$ postpartum. None of the animals was classified as an outlier in any of the models, and all observations were retained in the final analysis. Parity distribution resulted in 35 animals entering second parity, whereas 21 animals entered third or higher parity. Nineteen animals $(33.9 \%)$ were classified as HYK, whereas 37 animals $(66.1 \%)$ were classified as non-HYK. Detailed information about energy balance and DMI was described previously (Mann et al., 2015). All energy balance predictions were estimated using CNCPS software (version 6.1; Cornell University, Ithaca, NY). Briefly, average (SD) energy balance in group HE was 169 (15), 156 (22), and 122\% (18) of predicted requirements in wk 6, 4, and 1 prepartum, respectively, whereas in group CE it was 124 (11), 115 (12), and 91\% (12) of predicted requirements, respectively. Average (SD) energy balance postpartum in group HE was 66 

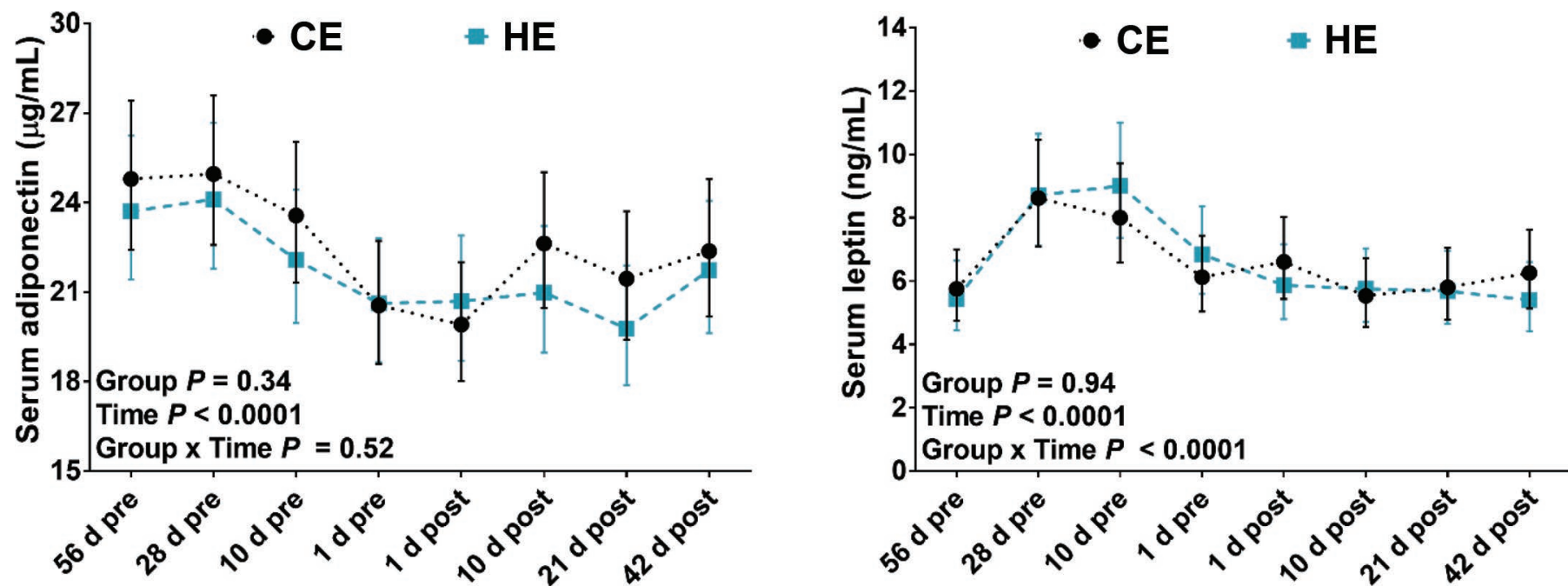

Figure 1. Peripartum serum adiponectin (left) and leptin (right) concentrations for animals fed a controlled-energy dry period diet (CE; $\mathrm{n}=28$ ) or a diet supplying approximately $150 \%$ of energy requirements during the dry period $(\mathrm{HE} ; \mathrm{n}=28)$. Geometric LSM and $95 \%$ CI are shown from repeated-measures ANOVA for time points $56 \mathrm{~d}$ prepartum to $42 \mathrm{~d}$ postpartum, including the fixed effects of group, time, parity (2 vs. $\geq 3$ ), average BCS during the study period, and the interaction between time and group. Color version available online.

(15), 71 (14), and $83 \%(7)$ of predicted requirements in wk 1, 3, and 6 postpartum, respectively, whereas in group CE it was 68 (10), 76 (11), and $87 \%$ (9) of predicted requirements, respectively.

Serum adiponectin and leptin concentrations changed over time $(P<0.0001)$. No association was found between adiponectin and treatment group $(P=$ 0.34; Figure 1). In contrast, an interaction of treatment group and time was found for leptin concentrations $(P$ $<0.0001$; Figure 1). Parity was associated with serum adiponectin concentrations $(P=0.04)$, and cows entering lactation 2 exhibited consistently higher concentrations of this adipokine throughout the study period (Figure 2). An interaction of parity and time was found for serum leptin concentrations $(P=0.02$; Figure 2).

The average BCS had a mean of 3.13 with a standard deviation of 0.26 and ranged from 2.7 to 4.0. The average BCS controlling for the effect of parity did not differ between treatment groups $[3.12(3.02-3.22)$ vs. $3.16(3.06-3.27) ; P=0.59]$; however, BCS was higher in
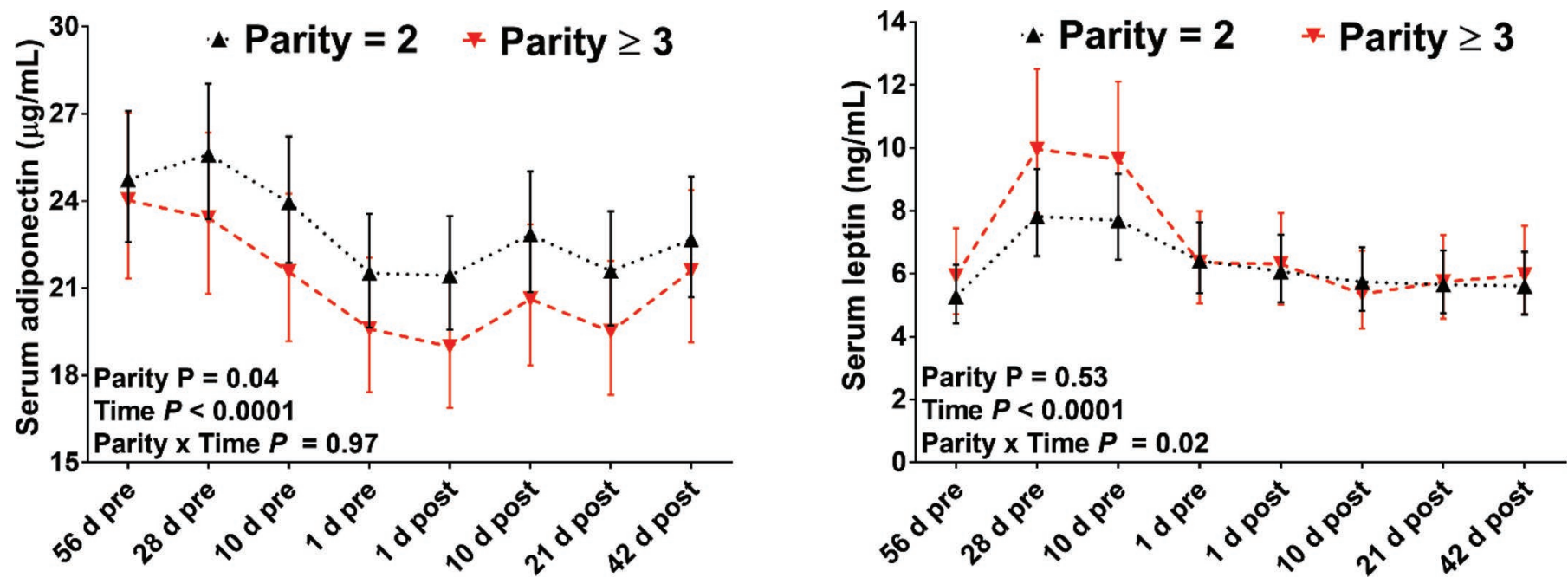

Figure 2. Peripartum serum adiponectin (left) and leptin (right) concentrations for animals entering second (parity 2; $\mathrm{n}=35$ ) or greater (parity $>3 ; \mathrm{n}=21$ ) lactation. Geometric LSM and $95 \% \mathrm{CI}$ are shown from repeated-measures ANOVA for time points $56 \mathrm{~d}$ prepartum to $42 \mathrm{~d}$ postpartum, including the fixed effects of parity ( 2 vs. $\geq 3$ ), group (controlled energy vs. high energy), time, average BCS during the sampling period, and the interaction between time and parity. Color version available online. 
animals entering third or higher lactation than in animals entering second lactation $[3.20(3.09-3.32)$ vs. 3.08 (2.99-3.17), $P=0.08]$, and their BFT was on average $2.6 \mathrm{~mm}$ greater $[6.95(5.81-8.10)$ vs. $4.38(3.48-5.27)$; $P=0.001]$. The BCS group was not associated with adiponectin concentrations $(P=0.59)$, and there was no interaction between BCS group and time for serum adiponectin $(P=0.65)$. In contrast, the model for serum leptin showed an interaction between BCS group and time $(P=0.05)$ that resulted from concentrations in the high BCS group being increased during the dry period compared with the low BCS group, whereas both groups had comparable leptin concentrations postpartum.

A total of 19 animals were classified as HYK (12 animals in group HE; 7 animals in group CE). Hyperketonemia status was associated with serum adiponectin concentrations $(P=0.001)$; cows that were classified as HYK had lower concentrations of this adipokine throughout the study period (Figure 3). In contrast, leptin concentrations showed no association with HYK $(P=0.47$; Figure 3$)$. Spearman rank correlations at the 4 time points in the transition period did not reveal any strong correlations between adiponectin or leptin with BFT, BCS, or DMI $(\mathrm{r}<0.23)$.

Our main objective was to determine a possible association between adipokine concentrations throughout the peripartum period and 2 different prepartum energy levels. Adiponectin concentrations were not associated with the treatment group but changed over time in a characteristic pattern similar to results described pre- viously using ELISA and Western blotting technique (Mielenz et al., 2013), Western blotting alone (Giesy et al., 2012), or ELISA alone (Singh et al., 2014b). Mielenz et al. (2013) and Singh et al. (2014b) showed that the nadir of circulating adiponectin was reached on $\mathrm{d} 0$ and 1 relative to calving, respectively, after which the concentration steadily increased until the end of the study period at 40 and $105 \mathrm{~d}$ postpartum, respectively. The absence of a statistical effect of prepartum energy balance on circulating adiponectin concentrations is somewhat surprising given that it is assumed that the decrease in adiponectin concentrations around parturition is at least partially attributable to the rapid decrease in energy availability (Singh et al., 2014a). Adiponectin was shown to decrease over a period of 15 wk of overconditioning in nonpregnant, nonlactating animals (Locher et al., 2015), but the animals in this study started from a very low level of energy supply, being fed with straw before the energy supply was increased. Energy supply and deficiency outside of the immediate periparturient period elicited no discernible effect on circulating adiponectin concentrations in dairy cows (Singh et al., 2014a). Based on this, it appears that differences in energy balance or body fat alone are not sufficient to cause changes in circulating adiponectin concentrations in the same magnitude as observed peripartum. This suggests that the rapid changes in the hormonal milieu as part of the physiological adaptation to lactation in combination with the increased metabolic turnover are driving the changes in adiponectin concentrations observed in the transition period.
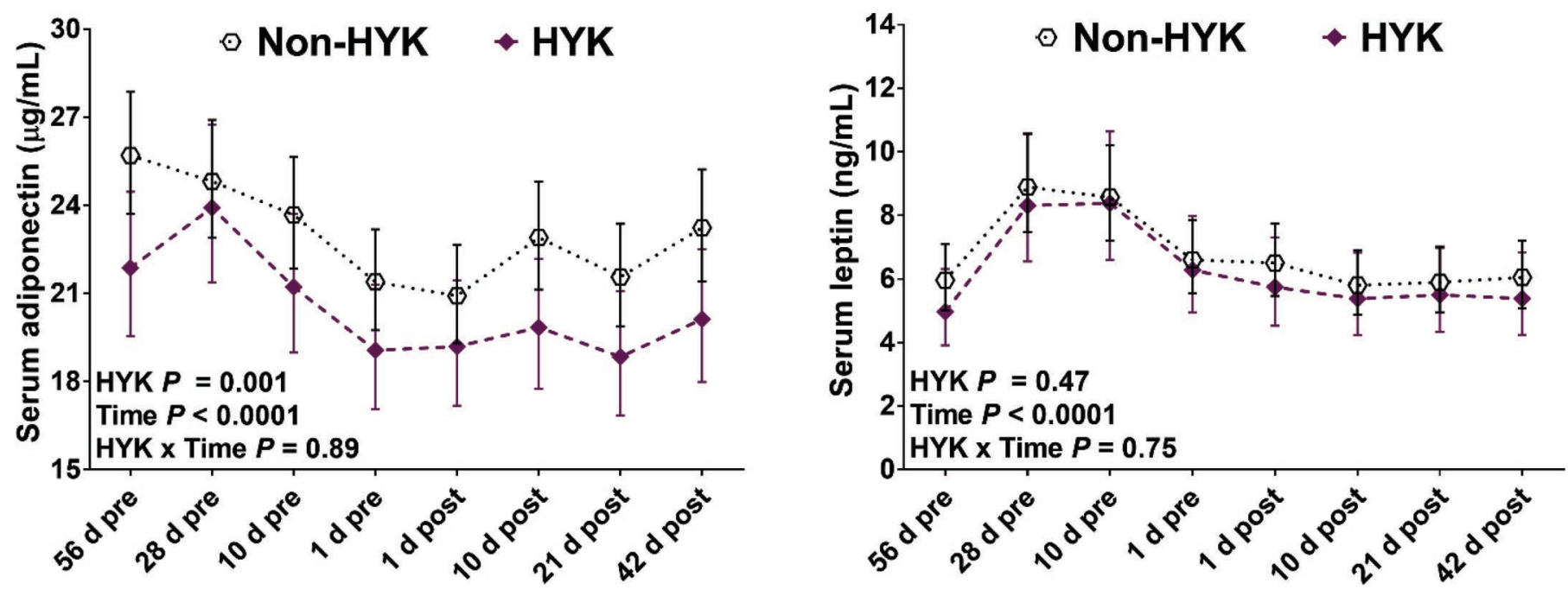

Figure 3. Peripartum serum adiponectin (left) and leptin (right) concentrations for animals that were classified as hyperketonemia positive $(\mathrm{mmol} / \mathrm{L}$ at least once) between $\mathrm{d} 3$ and 21 postpartum $(\mathrm{HYK} ; \mathrm{n}=19)$ or that did not show a hyperketonemic episode $($ non-HYK; $\mathrm{n}=37)$. Geometric LSM and 95\% CI are shown from repeated-measures ANOVA for time points $56 \mathrm{~d}$ prepartum to $42 \mathrm{~d}$ postpartum, including the fixed effects of HYK, parity ( 2 vs. $\geq 3$ ), group (controlled energy vs. high energy), time, average BCS during the study period, and the interaction between time and HYK status. Color version available online. 
The interaction between treatment group and time for leptin was caused by the higher concentration in cows overfed energy prepartum compared with cows fed a controlled-energy diet. The relationship between energy balance and leptin concentration was previously described in peripartum dairy cows and is thought to be attributable to the prioritization of energy expenditure to support milk production postpartum, whereas energy is stored in the prepartum period (Block et al., 2001). Leptin concentrations decreased postpartum after a characteristic increase during the dry period, similarly to the pattern described by Laeger et al. (2013) in the plasma of peripartum dairy cows. Body fat is positively associated with leptin concentration in calves (Ehrhardt et al., 2000) and adult cows (Kokkonen et al., 2005). We previously showed that BFT was increased in cows overfed energy compared with those fed a controlled-energy diet (Mann et al., 2016a), which may help explain the observed differences as this was demonstrated previously by Kokkonen et al. (2005). In addition to the interaction between treatment group and time for leptin that was controlled for average BCS during the study, we showed an interaction between BCS group and time after controlling for the effect of treatment group. It can thus be hypothesized that both dietary energy and BCS have a positive effect on leptin concentration in the prepartum period. In contrast with the results by Kokkonen et al. (2005) but in agreement with results by Pires et al. (2013), leptin concentration was similar in cows in the different BCS groups postpartum. Contrary to leptin, adiponectin concentrations were not associated with BCS in this study, which is in contrast to the negative association between BCS in the dry period and adiponectin concentration reported by De Koster et al. (2017). It should be noted that the BCS range in this study was smaller and generally lower compared with the above-mentioned studies by Pires et al. (2013), Kokkonen et al. (2005), and De Koster et al. (2017), which could explain our inability to detect an association between BCS and adiponectin concentration.

Parity group was associated with both adiponectin and leptin concentrations after controlling for the effect of treatment group and average body condition. Adiponectin was lower in older cows throughout the study period. Leptin was higher in older cows in the dry period only. It is possible that the slight differences in BCS and BFT may have contributed to this difference in adipokine concentrations between the different parity groups. When taking into account the absence of strong associations between parameters of body fatness and at least adiponectin in this study, we believe that these differences alone do not provide sufficient explanation for the observed differences, and additional unmeasured factors are associated with the observed parity effect.

Interestingly, adiponectin concentrations were lower throughout the study period in cows that developed hyperketonemia postpartum, but differences were not found between animals overfed energy or fed a controlled-energy diet. In a subset of animals (12 in each group) that were part of this study population, we previously showed that adiponectin gene expression was higher in subcutaneous adipose tissue of overfed animals that showed high BHB concentrations postpartum (Mann et al., 2016a). To reconcile the discrepancy between gene expression and serum concentrations, it would be necessary to study the fate of adiponectin after release into circulation, where it is present predominantly in the high-molecular-weight form (Giesy et al., 2012; Mielenz et al., 2013). Our results confirm the results by Hosseini et al. (2015), who showed a greater mRNA abundance of adiponectin in subcutaneous adipose tissue in overfed nonlactating, nonpregnant cows, yet serum concentration was reduced in that group compared with the control group. Likewise, Singh et al. $(2014 b)$ found no correlations $(\mathrm{r}<0.275)$ between serum adiponectin concentrations and gene expression in visceral and subcutaneous adipose tissue depots. Future studies should attempt to address the potential discrepancy between adiponectin gene expression in adipose tissue and circulating concentrations in transition dairy cows.

Given the difference in adiponectin in cows with and without hyperketonemia even before calving, future studies with an equally well-characterized study population that allows the determination of hyperketonemia status postpartum should determine whether this finding can be repeated to test the hypothesis that adiponectin concentrations are associated with the risk for hyperketonemia. If this is the case, reasons for individual differences in adiponectin concentrations in the transition period should be explored.

\section{ACKNOWLEDGMENTS}

This project was supported by the Agriculture and Food Research Initiative competitive grant no. 201267015-30230 from the USDA National Institute of Food and Agriculture (Washington, DC).

\section{REFERENCES}

Baird, G. D., R. J. Heitzman, K. G. Hibbitt, and G. D. Hunter. 1974. Bovine ketosis: A review with recommendations for control and treatment. Br. Vet. J. 130:214-220.

Block, S. S., W. R. Butler, R. A. Ehrhardt, A. W. Bell, M. E. Van Amburgh, and Y. R. Boisclair. 2001. Decreased concentration of 
plasma leptin in periparturient dairy cows is caused by negative energy balance. J. Endocrinol. 171:339-348.

Block, S. S., R. P. Rhoads, D. E. Bauman, R. A. Ehrhardt, M. A. McGuire, B. A. Crooker, J. M. Griinari, T. R. Mackle, W. J. Weber, M. E. Van Amburgh, and Y. R. Boisclair. 2003. Demonstration of a role for insulin in the regulation of leptin in lactating dairy cows. J. Dairy Sci. 86:3508-3515. https://doi.org/10.3168/ jds.S0022-0302(03)73955-1.

Chilliard, Y., C. Delavaud, and M. Bonnet. 2005. Leptin expression in ruminants: Nutritional and physiological regulations in relation with energy metabolism. Domest. Anim. Endocrinol. 29:3-22. https://doi.org/10.1016/j.domaniend.2005.02.026.

Dann, H. M., N. B. Litherland, J. P. Underwood, M. Bionaz, A. D'Angelo, J. W. McFadden, and J. K. Drackley. 2006. Diets during far-off and close-up dry periods affect periparturient metabolism and lactation in multiparous cows. J. Dairy Sci. 89:3563-3577. https://doi.org/10.3168/jds.S0022-0302(06)72396-7.

De Koster, J., C. Urh, M. Hostens, W. Van den Broeck, H. Sauerwein, and G. Opsomer. 2017. Relationship between serum adiponectin concentration, body condition score, and peripheral tissue insulin response of dairy cows during the dry period. Domest. Anim. Endocrinol. 59:100-104. https://doi.org/10.1016/j.domaniend.2016 .12 .004 .

Edmonson, A. J., I. J. Lean, L. D. Weaver, T. Farver, and G. Webster. 1989. A body condition scoring chart for Holstein dairy cows. J. Dairy Sci. 72:68-78. https://doi.org/10.3168/jds.S0022 $-0302(89) 79081-0$.

Ehrhardt, R. A., R. M. Slepetis, J. Siegal-Willott, M. E. Van Amburgh, A. W. Bell, and Y. R. Boisclair. 2000. Development of a specific radioimmunoassay to measure physiological changes of circulating leptin in cattle and sheep. J. Endocrinol. 166:519-528.

Giesy, S. L., B. Yoon, W. B. Currie, J. W. Kim, and Y. R. Boisclair. 2012. Adiponectin deficit during the precarious glucose economy of early lactation in dairy cows. Endocrinology 153:5834-5844. https://doi.org/10.1210/en.2012-1765.

Herdt, T. H. 2000. Ruminant adaptation to negative energy balance. Influences on the etiology of ketosis and fatty liver. Vet. Clin. North Am. Food Anim. Pract. 16:215-230.

Hosseini, A., M. R. Tariq, F. Trindade da Rosa, J. Kesser, Z. Iqbal, O. Mora, H. Sauerwein, J. K. Drackley, E. Trevisi, and J. J. Loor. 2015. Insulin sensitivity in adipose and skeletal muscle tissue of dairy cows in response to dietary energy level and 2,4-thiazolidinedione (TZD). PLoS One 10:e0142633. https://doi.org/10.1371/ journal.pone.0142633.

Janovick, N. A., Y. R. Boisclair, and J. K. Drackley. 2011. Prepartum dietary energy intake affects metabolism and health during the periparturient period in primiparous and multiparous Holstein cows. J. Dairy Sci. 94:1385-1400. https://doi.org/10.3168/jds.2010 -3303 .

Kesser, J., M. Hill, J. F. L. Heinz, C. Koch, J. Rehage, J. SteinhoffWagner, H. M. Hammon, B. Mielenz, H. Sauerwein, and H. Sadri. 2015. The rapid increase of circulating adiponectin in neonatal calves depends on colostrum intake. J. Dairy Sci. 98:7044-7051. https://doi.org/10.3168/jds.2015-9726.

Kokkonen, T., J. Taponen, T. Anttila, L. Syrjala-Qvist, C. Delavaud, Y. Chilliard, M. Tuori, and A. T. Tesfa. 2005. Effect of body fatness and glucogenic supplement on lipid and protein mobiliza- tion and plasma leptin in dairy cows. J. Dairy Sci. 88:1127-1141. https://doi.org/10.3168/jds.S0022-0302(05)72779-X.

Laeger, T., H. Sauerwein, A. Tuchscherer, O. Bellmann, C. C. Metges, and B. Kuhla. 2013. Concentrations of hormones and metabolites in cerebrospinal fluid and plasma of dairy cows during the periparturient period. J. Dairy Sci. 96:2883-2893. https://doi.org/10 .3168/jds.2012-5909.

Locher, L., S. Haussler, L. Laubenthal, S. P. Singh, J. Winkler, A. Kinoshita, A. Kenez, J. Rehage, K. Huber, H. Sauerwein, and S. Danicke. 2015. Effect of increasing body condition on key regulators of fat metabolism in subcutaneous adipose tissue depot and circulation of nonlactating dairy cows. J. Dairy Sci. 98:1057-1068. https://doi.org/10.3168/jds.2014-8710.

Mann, S., D. V. Nydam, A. Abuelo, F. A. Leal Yepes, T. R. Overton, and J. J. Wakshlag. 2016a. Insulin signaling, inflammation, and lipolysis in subcutaneous adipose tissue of transition dairy cows either overfed energy during the prepartum period or fed a controlled-energy diet. J. Dairy Sci. 99:6737-6752. https://doi.org/10 $.3168 /$ jds.2016-10969.

Mann, S., F. A. Yepes, M. Duplessis, J. J. Wakshlag, T. R. Overton, B. P. Cummings, and D. V. Nydam. 2016b. Dry period plane of energy: Effects on glucose tolerance in transition dairy cows. J. Dairy Sci. 99:701-717. https://doi.org/10.3168/jds.2015-9908.

Mann, S., F. A. Yepes, T. R. Overton, J. J. Wakshlag, A. L. Lock, C. M. Ryan, and D. V. Nydam. 2015. Dry period plane of energy: Effects on feed intake, energy balance, milk production, and composition in transition dairy cows. J. Dairy Sci. 98:3366-3382. https:// doi.org/10.3168/jds.2014-9024.

Mielenz, M., B. Mielenz, S. P. Singh, C. Kopp, J. Heinz, S. Häussler, and H. Sauerwein. 2013. Development, validation, and pilot application of a semiquantitative Western blot analysis and an ELISA for bovine adiponectin. Domest. Anim. Endocrinol. 44:121-130. https://doi.org/10.1016/j.domaniend.2012.10.004.

Pires, J. A. A., C. Delavaud, Y. Faulconnier, D. Pomiès, and Y. Chilliard. 2013. Effects of body condition score at calving on indicators of fat and protein mobilization of periparturient Holstein-Friesian cows. J. Dairy Sci. 96:6423-6439. https://doi.org/10.3168/jds.2013 $-6801$.

Sauerwein, H., E. Bendixen, L. Restelli, and F. Ceciliani. 2014. The adipose tissue in farm animals: A proteomic approach. Curr. Protein Pept. Sci. 15:146-155.

Sauerwein, H., U. Heintges, M. Hennies, T. Selhorst, and A. Daxenberger. 2004. Growth hormone induced alterations of leptin serum concentrations in dairy cows as measured by a novel enzyme immunoassay. Livest. Prod. Sci. 87:189-195. https://doi.org/10 .1016/j.livprodsci.2003.08.001.

Singh, S. P., S. Haussler, J. J. Gross, F. J. Schwarz, R. M. Bruckmaier, and H. Sauerwein. 2014a. Short communication: Circulating and milk adiponectin change differently during energy deficiency at different stages of lactation in dairy cows. J. Dairy Sci. 97:15351542. https://doi.org/10.3168/jds.2013-7598.

Singh, S. P., S. Häussler, J. F. L. Heinz, S. H. Akter, B. Saremi, U. Müller, J. Rehage, S. Dänicke, M. Mielenz, and H. Sauerwein. 2014b. Lactation driven dynamics of adiponectin supply from different fat depots to circulation in cows. Domest. Anim. Endocrinol. 47:35-46. https://doi.org/10.1016/j.domaniend.2013.12.001. 